\title{
Intentionally introduced species: more easily invited than removed
}

\author{
Han Xu $\cdot$ Xubin Pan $\cdot$ Yun Song • Ying Huang • \\ Minmin Sun $\cdot$ Shuifang Zhu
}

Received: 13 July 2013/Revised: 21 April 2014/Accepted: 16 May 2014/

Published online: 31 May 2014

(C) Springer Science+Business Media Dordrecht 2014

\begin{abstract}
Alien species are brought into countries world wide on a massive scale for agricultural production, ex situ conservation, landscape aesthetics, gardens, and ecosystem restoration. Unfortunately, some of these species have escaped and adversely impacted on regional as well as global biodiversity conservation and agricultural production. To reduce such risks, it is necessary to implement specific and effective measures. Since various government departments and institutions are involved in the management of alien species, it is difficult to prevent native and agroecosystems from being invaded by invited species. We propose the establishment of a supervision and inspection continuum over intentional species introduction, similar to that which exists in some countries over unintentional species introductions. Namely, a justification of the necessity to import, a risk assessment, assurances as to provision of an adequate containment facility assessment, and a damagelimitation protocol should that need to be invoked. These requirements should be satisfied before an alien species is knowingly imported, and the necessary follow-up supervision is important post- importation.
\end{abstract}

Keywords Import · Introduction management - Invasive species · Plant Health regulations · Unintentional species introduction · "Firewall" policy

Communicated by David Hawksworth.

H. Xu $(\bowtie) \cdot$ X. Pan · Y. Song · Y. Huang · S. Zhu $(\bowtie)$

Institute of Plant Quarantine, Chinese Academy of Inspection and Quarantine, Beijing 100029, China e-mail: xuhangin@gmail.com

S. Zhu

e-mail: zhushf020420@gmail.com

H. $\mathrm{Xu}$

Research Center for Eco-Environmental Sciences, Chinese Academy of Sciences, Beijing 100085, China

M. Sun

State Key Laboratory of Wood Identification and Quarantine, Zhangjiagang Entry-Exit Inspection and Quarantine Bureau, Zhangjiagang 215600, China 
As a threat to public health, agroecosystems, natural ecosystems, and biodiversity conservation, alien species enter new territories by various pathways, such as cultivation, commerce, and tourism, which have already been restricted by different measures and policies (Mack 1990; Reichard 1997; OTA 1993; Xu et al. 2012). Current policies in many countries, however, remain inadequate. Animal and plant species introduced for laudable ex situ conservation purposes in zoos or botanical gardens, for instance, may escape and threaten local biodiversity and agroecosystems. To minimize the risk, it is necessary to implement explicit and systematic regulatory and management policies.

Intentional and unintentional species introductions are two major patterns of anthropogenic biological invasion. While the former is invited, the latter is self-invited. Currently, ministries and departments of agriculture, environment, forestry, maritime matters, quarantine, and inspectorates endeavour to maintain a "Firewall" to prevent undesirable biological invasions by promulgating policies and legal instruments at a variety of scales. Unintended introduction of some alien species by international trade and the inadvertent transport by vehicles, people, their effects, and the packaging of goods has been contained to some extent by inspection and quarantine at borders, at least for organisms visible to the unaided eye. The overseeing of intended introduction of alien species, however, is inadequate in most if not all countries, although we recognise that it may prevent some major invasive plants from establishment. Fit-for-purpose laws and regulations, as well as clear responsibilities, should be encouraged to change the situation, but it has to be recognized that such procedures can never cope with propagules such as seeds or fungal spores inadvertently brought into a country on travellers' clothes, mud on shoes and tyres, and in or on packaging materials and shipped goods.

In the light of current policies, the intentional introduction of alien species for plant breeding, horticulture, biocontrol, ornamentals, erosion control, and scientific purposes has been encouraged in some countries by government/market agencies by the waiving of customs duties or reduced import taxes. The problem has been exacerbated by the absence of follow-up supervision of imported species, from containment facilities to the field, and the difficulty of controlling dispersal after species enter markets or nursery gardens. It has been said that "which species to import and release are ultimately cultural and political choices-choices about which kind of the world we want to live in", and the issue has become a common world concern" (Reichard 1997). We concur, but add that the evidential basis on which to make such choices is in most cases inadequate or flawed.

\section{Invited "Guests" around the world}

Alien species were often intentionally introduced with the best of intentions in the late 18th and early 19th centuries, for laudable purposes. However, just as guests invited to enhance a party may turn out to be unpleasant, positive aspects of introductions may turn into negative ones. That is especially so when there are no requirements for on-going follow-up assessments. In Australia, for instance, most of invasive alien plants were intentionally introduced, mainly as ornamentals for gardening (Hulme 2012). However, about 90 plant species have escaped from gardens into the wild in Australia, some of which have seriously threatened agriculture and the environment, costing farmers US \$100 M each year (AWC, Australian Weeds Committee, http://www.weeds.org.au/escapees.htm). In China, 186 plant species are known to have been intentionally introduced, including ornamentals, hedgerow species, ones for medical foraging, and conservation of water and soil. Globally, those 
sought-for and other plants, accounted for $63.92 \%$ of newly recorded invasive plants by the end of 2013 (Fig. 1). According to our statistics, among the world's 100 worst invasive alien species, 34 are plants, and $89 \%$ of those plants were intentionally introduced, leading to an annual loss of at least US \$6 Bn per year (GISD, Global Invasive Species Database, http://www.issg.org/database). Unintentionally introduced plants, however, may cause much less damage, but the invasive species may compete with, and even replace, indigenous vegetation (ISSG, Invasive Species Specialist Group, http://www.issg.org/database/ species/search.asp?st=100ss).

Botanical gardens, in support of conservation initiatives, intentionally introduce many species to grow on-site. Consequently, they are also primary sources from which species can escape and reestablish in the wild. Almost 1,775 botanical gardens and arboreta in 148 countries have introduced plants from other regions (BGCI, Botanic Gardens Conservation International, http://www.bgci.org/resources/history). Some gardens, however, might be stepping-stones for alien species. For instance, two-thirds of introduced plant species in Australia have escaped from botanical and private gardens, with the proportion expected to increase over time (Groves et al. 2005). In the continental United States, more than half the naturalized exotic plants were brought in for gardening (Randall and Marinelli 1996; Mack and Erneberg 2002). Cytisus scoparius (scotch broom), a highway plant, still grows in the western region of the United States, and was originally introduced as an ornamental plant and then promoted by the US Soil Conservation Service for erosion control (Oneto et al. 2009). Now it has spread to over 500,000 acres in California, where it elbows out the native biota (Smith 1995).

Nursery gardens, grasslands, timberlands, and intertidal zones are facing potential threats. Alien species promoted for restoration, food or feed, and horticulture may also have adverse effects, for example by becoming invasive and threatening native species. This is the case with new forage grasses, which usually have a unique ecological niche, and have been introduced for trials. It is easy for them to disperse due to their competitive advantages. Kochia scoparia was trialed as a saline-alkaline tolerant forage grass in northern Australia, dispersed later, on was soon eradicated (Dodd and Moore 1993). Gamba grass (Andropogon gayanus) first appeared in Queensland in cultivation, and in the

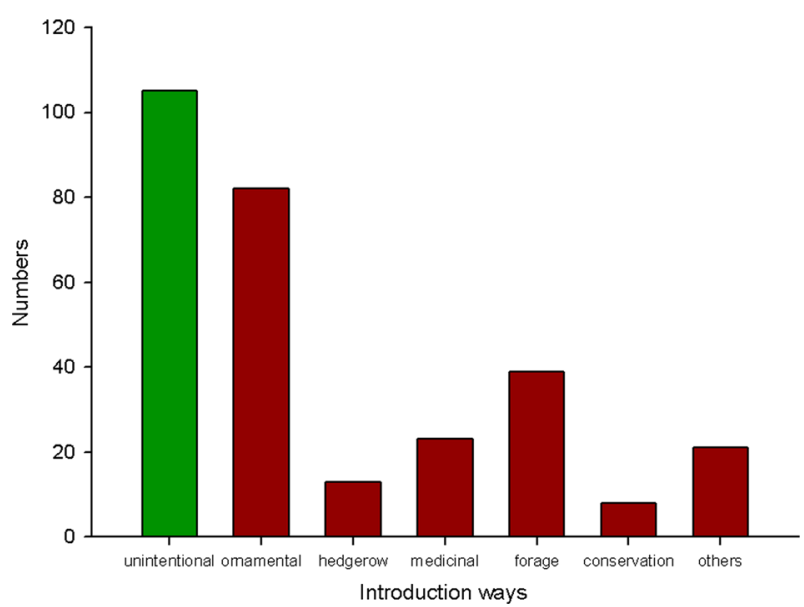

Fig. 1 Routes and quantities of alien invasive plants entering China in 2013 
Northern Territory in trials and plantings as a forage grass from Africa. It has become a dangerous weed, the $4 \mathrm{~cm}$-height and dry straws of which also constitute a fire hazard (DAFF, Department of Agriculture, Fisheries and Forestry, http://www.daff.qld.gov.au/ 4790_7005.htm).

Such threats occur in developed and developing regions of the world. Hulme (2011) found that many invasive plant species had escaped from Tanzania's botanical gardens. And that the gardens had failed to prevent species from being released into other regions (Hulme 2011). In order to contain the situation, the South African Nursery Association has categorized three kinds of introduced species not to be propagated, grown, bought or sold by the industry without a permit (SANA, The South African Nursery Association, http://www.sana.co.za/). In China, about $51 \%$ of alien plants have been deliberately introduced (Department of Supervision on Animal and Plant Quarantine, General Administration of Quality Supervision, Inspection and Quarantine, Beijing: China Zhijian Publishing House, unpubl. data).

Native to the American tropics, Lantana camara was introduced to China as an ornamental plant (Cronk \& Fuller 2001). Due to its allelopathy and influence on soil fertility and nutrient cycling, however, L. camara has displayed invasive features and soon spread into the vast tropical and subtropical areas of China (Osunkoya and Perrett 2011; Li and Xie 2002). In the absence of many of the associated fungi and insects that limit its vigour in its natural range, the species has become a problem in many parts of the world.

\section{Difficulty in guarding against invited species}

Compared with unintentionally introduced species, invited species are more likely to avoid supervision due to unawareness of their potential harm, especially if there has been no restrictions placed on them by any authority. Such plants can occupy favorable ecological niches and be sold freely, which helps overcome any propagule pressure and transportation bottleneck. In addition, cultivation and nurturing in horticulture, which may involve deliberate selection of genotypes, may pave the way for population establishment of the invitees (Crooks and Soule 1997). When follow-up supervision is missing, the invited "guests" may wander around freely, leading to faster outbreaks and a shorter "lag time" before becoming pests and cause huge damages (Sami et al. 2010; Richardson and Rejmanek 2011). The "lag time" of an invasion is the delay between arrival and the successful spread in a new area of an introduced species (McKey 1989; Crooks and Soule 1999; Daehler 2009). Although biological safety is usually assessed before introducing nursery stocks, the assessments can endeavour to take account of known potential epidemic problems, but generally ignores alien species that are not in any quarantine pest list. It is also hard to conduct a timely Pest Risk Analysis (PRA), not only because of the large numbers of alien species and urgent demands of traders, but also the properties of alien species with a known "lag time". It should be a key part of policy to strengthen follow-up administration and control plants within the "lag time". However, it has to be recognized that the behavior of a plant in a new region may be different from that in its native situation because of potential release from its normal pests.

\section{Current supervision over alien species}

Too many departments are involved in managing alien species, including those of agriculture, environment, quarantine and inspection, forestry, and fishery/marine, (Fig. 2). 


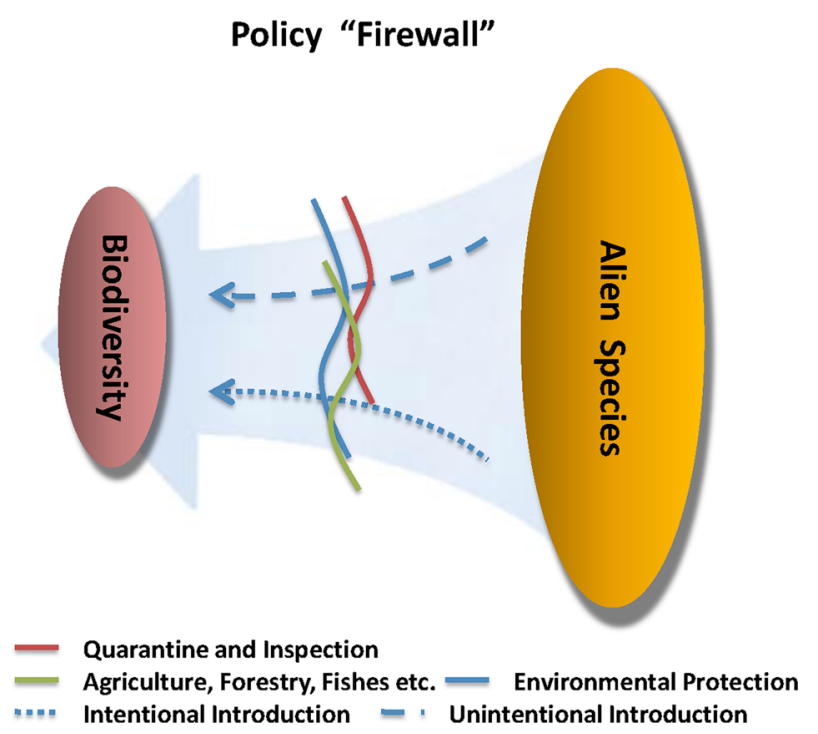

Fig. 2 Intentional and unintentional introductions passing the current Management "Firewall"

Each department has its own jurisdiction over imported products and species according to their functions and categories, and corresponding rules and regulations differ from one another. In the USA, USDA takes charge of the supervision of intentional and unintentional introductions (OTA 2006). In New Zealand, the Ministry of Agriculture and Forestry has a major role in managing unintentional species introduction, together with the ministries of environment, health etc., while it is just the ministry of environment which is primarily responsible for intentional species introductions (Christensen 2004). In addition, supervision of plant products coming into a country are confined to visual quarantine assessments for plant diseases caused by viruses, bacteria, or fungi, and such visual checks may not detect fungi on roots, for example, or ones growing in the plant tissues but not yet causing adverse effects. Any risk assessment of the species itself, such as potential invasiveness of introduced horticultural plants, is generally missing.

Among the various management systems for the import of live material, quarantine and inspection has formed a continuum mainly for importing products in international trades (Magarey et al. 2009). The continuum includes species identification, pest risk analysis, early warning, and follow-up supervision. The intentional introduction of alien species may lack such a continuum management system if no risk is perceived, and inadequate or no follow-up supervision then opens a window for free market circulation, abandoned by people, and occasional escape from gardens, etc., all of which would give the aliens an opportunity to invade new habitats.

To better manage "invited" and "self-invited" plant species, we can draw from their respective management experiences. Based on a survey on management strategies, unintentional species introduction are usually subject to inspection at ports or in factories, etc., while intentional species introduction is usually less supervised. According Caton (2006), different PRA (Pest Risk Analysis) pathways usually feature different management modes despite the existence of the almost universal functions of quarantine and inspection. Based on pathway risk analysis, the unintentional introduction of invasive species has clear routes 
of movement, and transport routes of some species have been identified. As long as invasive species are identified when monitoring, especially in defined pathways, they can be quickly removed by the quarantine department.

The supervision systems in place to cover the unintentional introduction of alien species via international trade can be adopted for nursery gardens, aquaria, grasslands, and intertidal zones, etc., where the intentionally introduced species are first cultivated. Since alien species and products are imported by various pathways, however, corresponding departments should collaborate with each other and take charge, so that we can trace and control the risks more effectively.

\section{Future commitment}

Although the supervision system over the unintentional introduction of alien species is effective and integrated in some countries, it is generally less rigorous and impractical for intentional introductions, especially isolation in quarantine. However, other prevention and control links can be followed, such as a necessity register, risk assessment, and containment facility assessment all necessary before introducing an alien species. Whatever department manages intentional species introductions, the first step in preventing invited invasive species is to make sure: (1) whether we really need to introduce them; and (2) whether introduced species may escape and damage the local biodiversity, or may support pathogens which could spread to native plants. Further, follow-up supervision is essential in order to regularize cultivation and trading. Considering the processes of habitat degradation and species succession, it will be of great significance to explore the establishment mechanisms of invasive species, which will help provide epidemic warnings and long-term on-going supervision.

At the same time, it is also important that regulatory systems do not preclude imports of living material for research and exploration purposes, as perhaps the most risk-free invited species are those invited only into laboratories, in contrast to those brought in unawares on or in clothing, vehicles, or packaging (Hawksworth and Dentinger 2013). There is a difficult line to draw, but it is important that regulation has a firm scientific base and is not a case of "one scenario fits all" or a simple matter of box-ticking.

Acknowledgments Views expressed in this manuscript reflect our personal perspectives. We thank our friends working in the Institute of Plant Quarantine, Chinese Academy of Inspection and Quarantine, for helpful discussions. This work was funded by the National Science \& Technology Pillar Program of China (2012BAK11B01, 2012BAK11B03), and the Special Fund Project for Fundamental Research of Chinese Academy of Inspection and Quarantine (2014JK010), and Science and Technology Plan Projects of Jiangsu Entry-Exit Inspection and Quarantine Bureau (2014KJ51), and Science and Technology Plan Projects of General Administration of Quality Supervision, Inspection and Quarantine of the People's Republic of China (AQSIQ) (2013IK290).

\section{References}

Caton BP (2006) A response to the ESA position paper on biological invasions. ESA 87:329-337

Christensen M (2004) Invasive species legislation and administration: New Zealand. In: Miller M, Fabian R (eds) Harmful invasive species: legal responses. Environmental Law Institute, Washington, pp 23-50

Cronk QCB, Fuller JL (2001) Plant invaders: the threat to natural ecosystems. Earthscan Publications, London 
Crooks JA, Soule ME (1997) Invasive species and biodiversity management. Kluwer Academic Publishers, Dordrecht

Crooks J, Soulé ME (1999) Lag times in population explosions of invasive species: causes and implications. In: Sandlund OT, Schei PJ, Viken A (eds) Invasive species and biodiversity management. Kluwer, Dordrecht, pp 103-125

Daehler CC (2009) Short lag times for invasive tropical plants: evidence from experimental plantings in Hawai. PLoS ONE 4(2):e4462

Dodd J, Moore JH (1993) Introduction and status of Kochiascoparia in Western Australia. In: Proceedings I of the 10th Australian Weeds Conference and 14th Asian Pacific Weed Science Society Conference, Brisbane, 6-10 September, pp 496-500

Groves RH, Boden R, Lonsdale WM (2005) Jumping the garden fence: invasive garden plants in Australia and their environmental and agricultural impacts. CSIRO Rep, Sydney

Hawksworth DL, Dentinger BT (2013) Antibiotics: relax UK import rule on fungi. Nature 496:169

Hulme PE (2011) Addressing the threat to biodiversity from botanic gardens. Trends Ecol Evol 26:168-174

Hulme PE (2012) Weed risk assessment: a way forward or a waste of time? J Appl Ecol 49:10-19

Li ZY, Xie Y (2002) Human activity and alien invasive species in: invasive alien species in China. China Forestry Publishing House, Beijing

Mack RN (1990) Catalog of woes. Nat Hist 99(3):44-53

Mack RN, Erneberg M (2002) The United States naturalized flora: largely the product of deliberate introductions. Ann Mo Bot Gard 89:176-189

Magarey RD, Colunga-Garcia M, Fieselmann DA (2009) Plant biosecurity in the United States: roles, responsibilities and information needs. BioSci 59:875-884

McKey D (1989) Population biology of figs: applications for conservation. Experientia 45:661-673

Oneto SR, DiTomaso JM, Kyser GB (2009) Pest Notes: Brooms. UC ANR Publication 74147, Statewide IPM Program, Agriculture and Natural Resources, University of California. http://www.ipm.ucdavis. edu/PMG/PESTNOTES/pn74147.html. Accessed July 2009

Osunkoya OO, Perrett C (2011) Lantana camara L. (Verbenaceae) invasion effects on soil physicochemical properties. Biol Fertil Soils 47:349-355

OTA, Office of Technology Assessment (1993) Harmful non-indigenous species in the United States, OTAF-565.U.S. Government Printing Office, Washington

OTA, Office of TechnologyAssessment (2006) Harmful non-indigenous species in the United States. Government Printing Office, Washington

Randall JM, Marinelli T (1996) Invasive plants: weeds of the global garden. Handbook No. 149. Brooklyn Botanical Garden, New York

Reichard S (1997) Learning from the past. Public Gard Spec Suppl 12(2):25-27

Richardson DM, Rejmanek M (2011) The global database of invasive trees and shrubs. Divers Distrib 17:788-809

Sami A, Duncan RP, Hulme PE (2010) Lag-phases in alien plant invasions: separating the facts from the artefacts. Oikos 119:370-378

Smith N (1995) Weeds of natural ecosystems: a field guide to environmental weeds of the Northern Territory. Environment Centre Northern Territory, Darwin

Xu H, Chen K, Pan XB, Zhu SF, Ouyang ZY (2012) Threats of invasive species for China caused by expanding international trade. Environ Sci Technol 46(13):7063-7064 